Research article

\title{
Effects of genotype and agro-ecological conditions on storability of soybean [Glycine max (L.) Merr.] seed
}

\author{
Grace J. Chirchir ${ }^{1 *}$, Maina Mwangi ${ }^{1}$, Desterio O. Nyamongo ${ }^{2}$ and \\ Joseph P. Gweyi-Onyango ${ }^{1}$ \\ ${ }^{1}$ Kenyatta University, School of Agriculture and Enterprise Development, Department of \\ Agricultural Science and Technology, Nairobi, Kenya \\ ${ }^{2}$ Genetic Resource Research Institute, Kenya Agriculture and Livestock Research Organization, Kenya \\ *Corresponding Author: gjchirchir@gmail.com \\ [Accepted: 11 March 2017]
}

\begin{abstract}
Soybean seed storability in the tropics is especially important due to rapid deterioration that varies with the environment, genotype and management practices. The objective of this study was to investigate soybean seed quality during storage as influenced by genotype and agroecological conditions in Meru South Sub-County, Kenya. Seeds of two commonly grown soybean genotypes- Gazelle and TGx 1740-2F (SB19) harvested in February 2013 were used to investigate seed storability. Seed samples $(2.5 \mathrm{~kg})$ were stored in gunny bags in a completely randomized design with three replications, giving a total of 6 experimental units per site. The storage treatments were set on farm under ambient conditions in two contrasting agro-ecologies: Upper Midlands II (altitude- $1529 \mathrm{~m}$ above sea level; temp.- 18.2-20.6 ${ }^{\circ} \mathrm{C}$ ) at Kirege and Lower Midlands IV (altitude- $1129 \mathrm{~m}$ above sea level; temp.- $21.0-23.5^{\circ} \mathrm{C}$ ) at Igambatuntu. Changes in seed quality were monitored at 0,123 and 246 days of storage by subjecting them to germination, electrical conductivity and accelerated aging tests. Data were analyzed using SAS 2009. Results revealed that smaller-seeded soybean genotype TGX 1740-2F was a better storer seed than larger seeded Gazelle as shown by a higher vigor at end 246 days ( 8 months) of storage. In addition, seed storage environmental conditions significantly influenced the degree of seed deterioration. Soybean seed stored at cooler Upper Midlands II had greater vigor than that stored at the warmer Lower Midlands IV agro-ecology. This study concludes that soybean seed deteriorates in storage and that genotype by environment interaction plays an important role in expression of seed storability. It is recommended that soybean be stored in the cooler higher agro-ecologies of the tropics for improved storability.
\end{abstract}

Keywords: Soybean - Seed storability - Genotype - Agro-ecology.

[Cite as: Chirchir GJ, Mwangi M, Nyamongo DO \& Gweyi-Onyango JP (2017) Effects of genotype and agroecological conditions on storability of soybean [Glycine max (L.) Merr.] seed. Tropical Plant Research 4(1): 126-133]

\section{INTRODUCTION}

Availability of high quality seed that ensure adequate plant stand is necessary for the production and expansion of soybean. Between harvest and the next planting season farm- saved seed is usually stored under ambient tropical storage conditions. The preservation of seed viability and quality in storage is an important trait both for food usage and for seed use (Bentsink et al. 2000). Generally, viability and quality of seeds gradually deteriorate after harvest (Coolbear 1995, McDonald 1999), but the deterioration in long-term storage depends on environment, biochemical, biological, and genetic factors. Loss of seed viability and vigor under high temperature and RH conditions is a common phenomenon in many crop seeds (Balešević-Tubić et al. 2010) but it is well marked in soybean (Burris 1980, Tatipata 2009). Field seed storage conditions of high humidity and temperature synergistically accelerate physiological deterioration and pathological damage of seed. In addition, significant genotypic differences in soybean seed storability have been found by several researchers (Kurdikeri et al. 1996, Shelar 2002, El-Abady et al. 2012, Wien \& Kueneman 1981). Such differences have been attributed 
to biochemical characteristics of soybean genotypes which affect the degree of seed damage and the ability of seed to resist the negative consequences of aging (Balešević-Tubić et al. 2011). Genetic factors such as hardseediness, seed size, seed coat color, resistance to diseases and seed chemical composition influence the expression of seed vigor (AOSA 2009). Soybean seed quality deterioration has been associated with large seed size and permeable seed coats (Horlings et al. 1991). Soybean seed size was found to have a direct effect on seed germination and vigor (Sung 1992). In addition, a strong negative correlation was found between germination and seed weight among soybean genotypes (Singh et al. 1978). However, the physiological and biochemical mechanisms by which this variability is expressed are still not fully understood, although it has been found to be significantly influenced by genotype, environment, management practices and their interactions (Bellaloui et al. 2011). Hence, in the present investigation, efforts have been made to study the storability of soybean as influenced by genotype and contrasting storage agro-ecological conditions of Meru South sub-county of Kenya.

\section{MATERIALS AND METHODS}

\section{Site description:}

The storage experiment was conducted in Meru South Sub-county of Kenya, in two soybean growing areas, representative of the environmental conditions soybean seed would be subjected to in a typical farmer's storage facility. Site 1 was at Kirege village located at $00^{\circ} 20.580^{\prime}$ 'S, $037^{\circ} 37.189^{\prime}$ E, a higher altitude (1529 m above sea level ) site within cooler humid agro-ecological zone - Upper Midlands II (UM2) with an annual mean temperature of 18.2 to $20.6^{\circ} \mathrm{C}$ (Jaetzold et al. 2006). Site 2 was at Igambatuntu Village located at $00^{\circ}$ 06'19.4'N, 037 54' 49.7''E; altitude 1129 m above sea level, which represented the warmer semi-humid agroecological zone - Lower Midlands IV (LM4) with annual mean temperature of 21.0 to $23.5^{\circ} \mathrm{C}$ (Jaetzold et al. 2006 ).

\section{Experimental layout:}

Farm saved seed of two commonly grown soybean genotypes Gazelle and TGx 1740-2F (SB19), harvested in February 2013 were used in the experiment. The seed was obtained from two farmers from areas representative of Upper Midlands III agro-ecology in Meru South and Maara Sub-counties in February 2013. Seed samples $(2.5 \mathrm{~kg}$ ) from each seed lot was stored in three replicates in synthetic gunny bags (Biryani Pakistani Rice bags, M/S.H.M Traders) and tied with a sisal twine giving a total of 6 experimental units per site. The storage treatments were set in continuous non-climate controlled farmers' in-house stores, in a Completely Randomized Design (CRD) with three replications and stored for eight months from $14^{\text {th }}$ March 2013 to $14^{\text {th }}$ November 2013. The seeds were sampled after 0,123 and 246 days $(0,4$ and 8 months respectively) of storage for quality tests at the Genetic Resource Research Institute Laboratories (S $01^{\circ} 12.955^{\prime}$; E $036^{\circ} 37.859^{\prime}$, altitude $2100 \mathrm{~m}$ above sea level, AEZ LH3). The seed moisture, standard germination, electrical conductivity and the accelerated aging tests (AOSA 2009) were performed to monitor any changes in seed quality during storage.

\section{0 seed weight:}

Weight of 1000 seeds was evaluated by randomly sampling seeds from each seed lot, counting and weighing them. The values were then corrected at $13 \%$ moisture content.

\section{Determination of seed moisture:}

Seed moisture contents were determined using a Grain moisture meter (GMK-303RS, G-Won Hitech Co. Ltd) which measures the electric properties of seed moisture either by conductivity or capacitance within the range of 6-25\% range. Four replicates per seed lot were sampled, placed inside the moisture meter, ground and readings taken.

\section{Germination tests:}

Seeds of soybean [Glycine max (L.) Merr.] were treated for 40 seconds with sodium hypochlorite solution (3.85\% active ingredient) diluted with water in 1:2 ratio for 40 seconds and then surface washed with distilled water three times, to retard saprophytic fungal growth. Seeds were then germinated by placing 50 seeds per replication in four replicates in germination boxes using $500 \mathrm{ml}$ plastic containers with lids, containing $1 \%$ water agar under laboratory conditions (ISTA 2007). The germination boxes were arranged in a completely randomized design (CRD) in a walk-in germination chamber with alternating $12 \mathrm{~h}$ fluorescent light at $30^{\circ} \mathrm{C}$ and 
12 hours darkness at $20^{\circ} \mathrm{C}$. Counts of germinating seeds were made daily, starting on the first day of imbibitions and terminated 11 days after sowing, when maximum germination was obtained. Seeds were identified as germinated when $2 \mathrm{~mm}$ of the radicals protruded (ISTA 2007). Normal seedlings were recorded for calculating germination percentage (GP) at last count. Germination percent (GP) was calculated as follows:

\section{Electrical Conductivity test:}

$$
\mathrm{GP}=\frac{\text { Number of germinated seeds }}{\text { Total number of seeds sown }} \times 100
$$

Electrical conductivity tests were determined by weighing four replicate samples of 50 seeds per treatment and placing them in $250 \mathrm{ml}$ plastic cups containing $200 \mathrm{ml}$ of distilled water. The seeds were gently stirred to remove air bubbles. Any floating seeds were removed and the cups covered with aluminum foil. The seeds were then left to soak in the water for 24 hours at room temperature $20 \pm 2{ }^{\circ} \mathrm{C}$. Conductivity of seed leachates (electrical conductivity) was measured using a Jenway 4020 conductivity meter and CRT-CAA- 515B electrode dip type cell (Fisons Scientific Equipment) The conductivity meter was standardized with $0.01 \mathrm{~N}$ potassium Chloride. The solution was prepared afresh by dissolving $0.7456 \mathrm{~g} \mathrm{KCl}$ in $1,000 \mathrm{ml}$ of distilled water at room temperature. The cell constant $(\mathrm{K})$ value at 1.000 , and temperature coefficient per ${ }^{\circ} \mathrm{C}$ of $2 \%$ rise at $25^{\circ} \mathrm{C}$ was used to take the readings. The electrical conductivity of a control sample of an equivalent quantity of distilled water was also determined. Conductivity was expressed on a weight basis in micro Siemens per $\mathrm{cm}$ per gram $\left(\mu \mathrm{s} . \mathrm{cm}^{-1} \cdot \mathrm{g}^{-1}\right)$ of seed (ISTA 2007).

\section{Accelerated ageing test:}

For each seed lot, seeds were first preconditioned by exposing them to humid environment, created by placing seeds in open trays, above a water pan at room temperature for 48 hours in order to raise the seed moisture content to between $10 \%$ and $14 \%$. After allowing the seed moisture to equilibrate, 100 seed weight, adjusted to $13 \%$ moisture content was taken. Accelerated aging tests were then conducted by placing four replicates of 100 seeds per seed lot on a screen inside a $38 \times 28 \times 10 \mathrm{~cm}$ accelerated aging boxes (Hoffman Manufacturing Company, Albany, OR) containing $500 \mathrm{ml}$ of distilled water. The boxes were tightly sealed and placed in an ageing chamber maintained at $41^{\circ} \mathrm{C}$ and 100 per cent relative humidity for 72 hours (Delouche 1965). At the end of ageing, germination tests were conducted in four replicates of 50 seeds per seed lot on $1 \%$ water agar in a germination chamber with alternating $12 \mathrm{~h}$ darkness $\left(20^{\circ} \mathrm{C}\right)$ and $12 \mathrm{~h}$ of fluorescent light $\left(30^{\circ} \mathrm{C}\right)$. The ageing response was measured based on accelerated ageing germination percent of normal seedlings (ISTA 2007).

\section{Statistical analysis:}

Data were analyzed using PROC GLM (GLM Procedure) model of the Statistical Analysis Systems software. Parameters were subjected to Analysis of Variance (ANOVA) and means separated using Least Significance Difference (LSD) at $p<0.05$ based on Tukey's Studentized Range (HSD) test.

\section{RESULTS}

The means of seed viability and vigor for tested genotypes of soybean - TGx1740- 2F (SB 19) and Gazelle before and after storage in both storage agro-ecological conditions of Upper Midlands II (UM2) and Lower Midlands IV (LM4) was investigated. Results revealed that seed quality traits during storage varied amongst tested genotypes and storage environments, with statistically highly significant differences $(p<0.05)$.

Effects of genotype on storability of soybean seed

The genotypic differences in seed viability and vigor of soybean genotypes SB 19 (TGx1740-2F) and Gazelle in storage under ambient conditions was significant $(p<0.05)$. There were significant differences in 1000-seed weight between the soybean genotypes (Table 1).

Table 1. Seed weight of soybean genotype Gazelle and TGx 1740-2F.

\begin{tabular}{lll}
\hline Genotype & 1000 Seed weight & Seed coat color \\
\hline Gazelle & $159.20 \mathrm{a}$ & Cream \\
TGx1740 2F (SB19) & $119.60 \mathrm{~b}$ & Cream \\
LSD $_{0.05}$ & 7.52 & - \\
\hline Note: Values followed by the same letter(s) in each column are not significantly different $(\mathrm{p}<0.05)$
\end{tabular}


Genotype Gazelle (159.2 g) had a higher 1000 seed weight than TGx 1740-2F (119.6 g). Although both soybean genotypes were of cream seed coat color, Gazelle was larger seeded than TGx 1740-2F. Further, soybean genotypes seed viability and vigor during storage showed marked differences (Tables 2 \& 3 and Fig. 1). The seed moisture content fluctuated during storage but generally increased over the 246 DAS from a minimum of $7.4 \%$ to a maximum of $8.9 \%$. However genotypic differences in seed percentage moisture content varied with site and storage duration.

Table 2. Genotypic differences in studied traits of soybean seed during storage at Upper Midlands II (UM2) Kirege Meru South Sub-county.

\begin{tabular}{|c|c|c|c|c|c|c|c|c|c|}
\hline \multirow{3}{*}{$\begin{array}{l}\text { Soybean } \\
\text { Genotype }\end{array}$} & \multicolumn{3}{|c|}{$\begin{array}{l}\text { Seed Moisture } \\
\text { Content }(\%)\end{array}$} & \multicolumn{3}{|c|}{$\begin{array}{c}\text { Electrical conductivity } \\
\left(\mu \mathrm{s} . \mathrm{cm}^{-1} \cdot \mathrm{g}^{-1}\right)\end{array}$} & \multicolumn{3}{|c|}{$\begin{array}{c}\text { Final } \\
\text { Germination }(\%)\end{array}$} \\
\hline & $\overline{0}$ & 123 & 246 & 0 & 123 & 246 & $\mathbf{0}$ & 123 & 246 \\
\hline & DAS & DAS & DAS & DAS & DAS & DAS & DAS & DAS & DAS \\
\hline Gazelle & $7.43 b$ & $9.36 \mathrm{a}$ & $8.93 a$ & $42.98 b$ & $47.85 \mathrm{a}$ & $44.96 b$ & $93.50 \mathrm{~b}$ & $97.67 \mathrm{a}$ & $97.08 \mathrm{a}$ \\
\hline TGx1740-2F & $7.47 \mathrm{a}$ & $9.35 \mathrm{a}$ & $8.66 b$ & $46.53 a$ & $47.38 \mathrm{a}$ & $47.37 \mathrm{a}$ & $97.00 \mathrm{a}$ & $97.42 \mathrm{a}$ & $96.83 a$ \\
\hline LSD & 2.87 & 0.07 & 0.07 & 2.119 & 2.736 & 1.86 & 2.567 & 1.271 & 1.59 \\
\hline$r^{2}$ & 1.00 & 0.99 & 0.99 & 0.69 & 0.82 & 0.82 & 0.46 & 0.24 & 0.22 \\
\hline
\end{tabular}

Note: Values followed by the same letter(s) in each column are not significantly different $(\mathrm{p}<0.05)$. DAS = Days after storage, UM2-Upper Midland II Agro-ecology.

Table 3. Genotypic differences in studied traits of soybean seed during storage at Lower Midlands IV (LM4) Igambatuntu, Meru South Sub-county.

\begin{tabular}{|c|c|c|c|c|c|c|c|c|c|}
\hline \multirow{3}{*}{$\begin{array}{l}\text { Soybean } \\
\text { Genotype }\end{array}$} & \multicolumn{3}{|c|}{$\begin{array}{l}\text { Seed Moisture } \\
\text { Content }(\%)\end{array}$} & \multicolumn{3}{|c|}{$\begin{array}{l}\text { Electrical conductivity } \\
\left(\mu \mathrm{s} . \mathrm{cm}^{-1} \cdot \mathrm{g}^{-1}\right)\end{array}$} & \multicolumn{3}{|c|}{$\begin{array}{c}\text { Final } \\
\text { Germination }(\%)\end{array}$} \\
\hline & $\overline{0}$ & 123 & 246 & 0 & 123 & 246 & $\mathbf{0}$ & 123 & 246 \\
\hline & DAS & DAS & DAS & DAS & DAS & DAS & DAS & DAS & $\mathbf{A S}$ \\
\hline Gazelle & $7.43 b$ & $8.23 a$ & $7.61 \mathrm{a}$ & $42.98 b$ & $48.55 b$ & $50.25 a$ & $93.50 \mathrm{~b}$ & $97.0 \mathrm{a}$ & $93.25 a$ \\
\hline TGx 1740-2F & $7.47 \mathrm{a}$ & $8.08 b$ & 7.71a & $46.53 \mathrm{a}$ & $51.75 \mathrm{a}$ & $50.89 a$ & $97.00 \mathrm{a}$ & $96.4 \mathrm{a}$ & $92.75 \mathrm{a}$ \\
\hline $\mathrm{LSD}_{0.05}$ & 2.871 & 0.05 & 0.10 & 2.12 & 1.92 & 2.29 & 2.56 & 2.13 & 2.48 \\
\hline$r^{2}$ & 1.00 & 0.96 & 0.84 & 0.69 & 0.90 & 0.49 & 0.46 & 0.17 & 0.41 \\
\hline
\end{tabular}

Note: Values followed by the same letter(s) in each column are not significantly different $(\mathrm{p}<0.05)$, DAS = Days after storage, LM4=Lower Midlands IV Agro-ecology.

Throughout storage, both LM4 and UM2 agro-ecologies, soybean seed maintained a high germination percent of above $92 \%$ (Table $2 \& 3$ ). Genotypic differences in germination $\%$ were only observed at the onset of storage with TGx-1740-2F (97\%) having higher viability than Gazelle (93.5\%) but with no differences by 123 and 246 DAS.

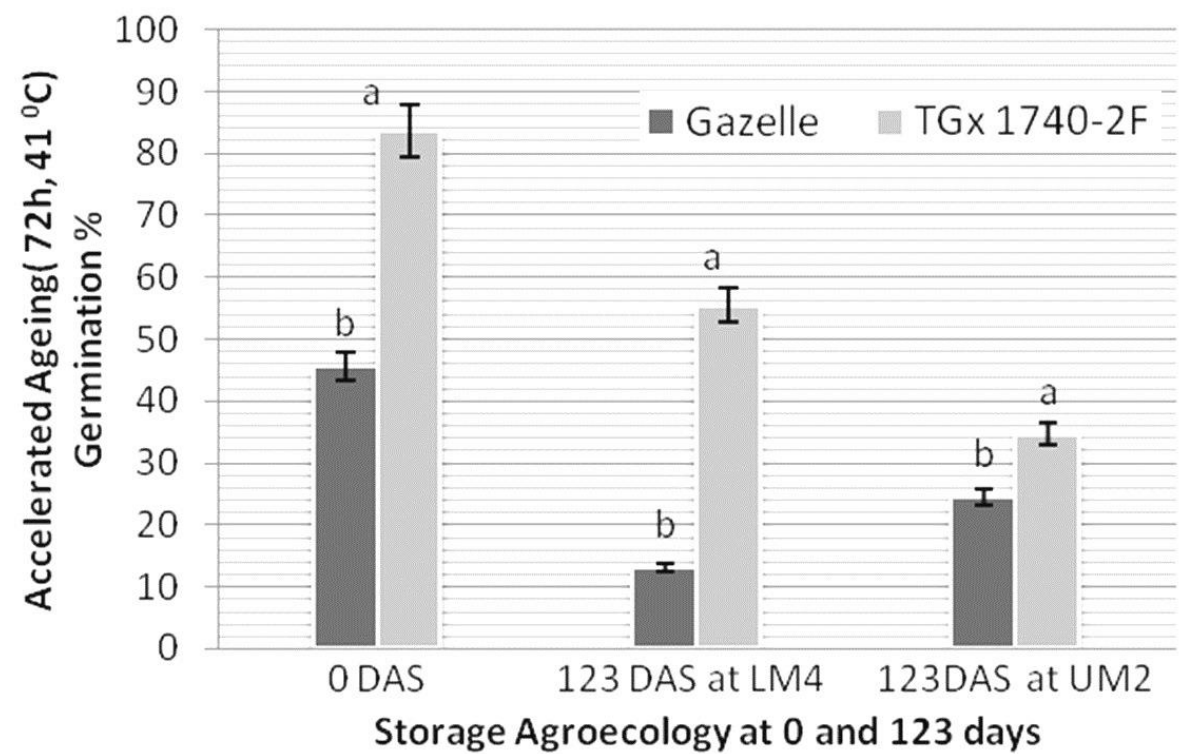

Figure 1. Genotypic differences in accelerated ageing $\left(72 \mathrm{~h}, 41^{\circ} \mathrm{C}\right)$ germination percent of soybean seed during storage at Lower Midlands IV (LM4) and Upper Midlands II (UM2) after 0 and 123 days of storage. 
Seed vigor however reduced over time, with significant genotypic differences across sites and storage durations as shown by the seed leachate conductance (Tables $2 \& 3$ ) and accelerated ageing germination \% (Fig. 1). The electrical conductivity (EC) of seed membrane leachates generally increased during storage, signifying deterioration of seed membranes with aging. By the end of storage (246 days) the EC values of the genotypes were not significantly different at the warmer LM4 storage site. However, at the cooler UM2 storage site, seed leachate conductance was higher for TGx 1740-2F $\left(47.3 \mu \mathrm{s} . \mathrm{cm}^{-1} . \mathrm{g}^{-1}\right)$ than Gazelle $\left(44.9 \mu \mathrm{s}_{\mathrm{cm}} \mathrm{cm}^{-1} \mathrm{~g}^{-1}\right)$, probably implying that membrane integrity varied with site and genotype. In addition, the accelerated ageing (AA) germination percent prior to storage and after 123 days of storage (Fig. 1), revealed significantly higher vigor of the small seeded genotype TGx-1740-2F than the larger seeded genotype Gazelle at both seed storage sites.

At onset of storage, TGx 1740-2F (83.7\%) had a higher vigor than Gazelle (45.7\%). After 123 days of storage, the Accelerated Ageing germination \%, hence seed vigor reduced with aging to $34.7 \%$ and $55.8 \%$ for smaller seeded TGx 1740-2F which was still significantly higher than for the larger seeded genotype Gazelle $(24.5 \%$ and $13.1 \%)$ at the UM2 and LM4 storage agro-ecologies respectively.

\section{Effect of seed storage agro-ecology on storability of soybean}

A considerable variation in soybean seed germination and vigor across different seed storage agro-ecologies of Meru South Sub-county are presented on tables 4 and 5. The results revealed that storage agro-ecology significantly affected the seed germination and vigor of soybean $(p<0.05)$.

Table 4. Effects of seed storage agro-ecology on soybean seed germination and vigor in year 2013 in Meru South SubCounty.

\begin{tabular}{|c|c|c|c|c|c|c|c|c|c|c|}
\hline \multirow{3}{*}{$\begin{array}{l}\text { Soybean } \\
\text { genotype }\end{array}$} & \multirow{3}{*}{$\begin{array}{l}\text { storage } \\
\text { Agro- } \\
\text { ecology }\end{array}$} & \multicolumn{3}{|c|}{$\begin{array}{c}\text { Seed Moisture } \\
\text { Content }(\%)\end{array}$} & \multicolumn{3}{|c|}{$\begin{array}{l}\text { Electrical Conductivity } \\
\left(\mu \mathrm{s} . \mathrm{cm}^{-1} \cdot \mathrm{g}^{-1}\right)\end{array}$} & \multicolumn{3}{|c|}{$\begin{array}{c}\text { Final } \\
\text { Germination }(\%)\end{array}$} \\
\hline & & 0 & 123 & 246 & $\mathbf{0}$ & 123 & 246 & $\mathbf{0}$ & 123 & 246 \\
\hline & & DAS & DAS & DAS & DAS & DAS & DAS & DAS & DAS & DAS \\
\hline \multirow{3}{*}{ Gazelle } & UM2 & $7.43 \mathrm{a}$ & $9.36 a$ & $8.93 a$ & $42.98 \mathrm{a}$ & $47.84 a$ & $44.96 \mathrm{~b}$ & $93.50 \mathrm{a}$ & $97.66 \mathrm{a}$ & $97.08 \mathrm{a}$ \\
\hline & LM4 & $7.43 a$ & $8.23 b$ & $7.61 b$ & $42.98 \mathrm{a}$ & $48.55 \mathrm{a}$ & $50.25 \mathrm{a}$ & $93.50 \mathrm{a}$ & $97.00 \mathrm{a}$ & $93.25 b$ \\
\hline & $\mathrm{LSD}_{0.05}$ & 2.87 & 0.02 & 0.02 & 2.11 & 2.07 & 1.95 & 2.56 & 2.04 & 2.12 \\
\hline TGx 1740- & UM2 & $7.47 \mathrm{a}$ & $9.35 a$ & $8.60 \mathrm{a}$ & $46.53 a$ & $47.38 b$ & $47.37 b$ & $97.00 \mathrm{a}$ & $97.41 \mathrm{a}$ & $96.83 \mathrm{a}$ \\
\hline \multirow[t]{2}{*}{$2 \mathrm{~F}(\mathrm{SB} 19)$} & LM4 & $7.47 \mathrm{a}$ & $8.08 \mathrm{~b}$ & $7.71 b$ & $46.53 \mathrm{a}$ & $51.75 \mathrm{a}$ & $50.89 \mathrm{a}$ & $97.00 \mathrm{a}$ & $96.41 \mathrm{a}$ & $92.75 b$ \\
\hline & $\mathrm{LSD}_{\mathbf{0 . 0 5}}$ & 2.87 & 0.05 & 0.01 & 2.11 & 2.43 & 2.14 & 2.56 & 1.23 & 2.06 \\
\hline
\end{tabular}

Note: Values followed by the same letter(s) in each column are not significantly different $(\mathrm{p}<0.05)$; Upper Midland II (UM2) Kirege site and Lower Midland IV (LM4) Igambatuntu site.

Table 5. Effects of seed storage agro-ecology on soybean seed vigor by Accelerated ageing $\left(72 \mathrm{~h}, 41^{\circ} \mathrm{C}\right)$ germination percent in year 2013 in Meru South Sub-County.

\begin{tabular}{lllll}
\hline \multirow{2}{*}{ Seed storage agro-ecology } & \multicolumn{2}{l}{ Soybean TGX-1740-2F } & \multicolumn{2}{l}{ Soybean GAZELLE } \\
\cline { 2 - 5 } & 0 DAS & 123DAS & 0 DAS & 123DAS \\
\hline UM2 & $83.66 \mathrm{a}$ & $55.58 \mathrm{a}$ & $45.66 \mathrm{a}$ & $24.50 \mathrm{a}$ \\
$\mathrm{LM} 4$ & $83.66 \mathrm{a}$ & $34.67 \mathrm{~b}$ & $45.66 \mathrm{a}$ & $13.08 \mathrm{~b}$ \\
$\mathrm{LSD}_{0.05}$ & 3.558 & 7.622 & 10.27 & 9.493 \\
$\mathrm{r}^{2}$ & 0.48 & 0.85 & 0.69 & 0.64 \\
\hline
\end{tabular}

Note: Values followed by the same letter(s) in each column are not significantly different $(\mathrm{p}<0.05)$; DAS = Days after storage, LM4=Lower Midlands IV Agro-ecology (Kirege site) and UM2=Upper Midland II agro-ecology (Igambatuntu site).

Soybean seed stored in cooler $\left(18-21^{\circ} \mathrm{C}\right)$ Upper Midlands II- (UM2) had significantly higher seed moisture than seed stored in warmer LM4 $\left(21-24^{\circ} \mathrm{C}\right)$ by the end of 246 days of storage. However, despite the increased moisture levels, seed stored better in the cooler agro-ecology of UM2 than the warmer LM4 as shown by the higher seed germination and vigor. At the end of storage, germination percent was significantly higher at UM2 for Gazelle (97\%) and TGx 1740-2F (96.8\%) as compared to the warmer LM4 with Gazelle (93.2\%) and TGx $1740-2 \mathrm{~F}(92.7 \%)$. Also seed vigor was higher at cooler UM2 than at warmer LM4 agro-ecology as shown by the reduced seed leachates of Gazelle $\left(44.9 \mu \mathrm{s} . \mathrm{cm}^{-1} \cdot \mathrm{g}^{-1}\right)$ and TGx 1740-2F $\left(47.4 \mu \mathrm{s} . \mathrm{cm}^{-1} \cdot \mathrm{g}^{-1}\right)$ than at LM4 with Gazelle $\left(50.3 \mu \mathrm{s} . \mathrm{cm}^{-1} \cdot \mathrm{g}^{-1}\right)$ and TGx $1740-2 \mathrm{~F}\left(50.9 \mu \mathrm{s} . \mathrm{cm}^{-1} \cdot \mathrm{g}^{-1}\right)$. Similarly, seed vigor test by accelerated ageing (Table 5) after 123 days of storage showed that soybean seeds were of lower vigor at the warmer LM4 agroecology with TGx 1740-2F (34.67\%) and Gazelle (13.08\%) than at the cooler UM2 with TGx $17402 \mathrm{~F}$ 
$(55.58 \%)$ and Gazelle (24.5\%). These observations suggest greater deterioration of seed membranes and seed ageing in warmer LM4 than at the cooler UM2 agro-ecology.

\section{DISCUSSION}

The demand for soybean in Kenya is continuously growing but poor seed viability and vigor between harvest and next planting season is a constraint towards its production. Genetic and environmentally based variation on soybean seed storability was observed in the study.

\section{Effects of genotype on storability of soybean seed}

Differences in the initial level of deterioration or ageing of seed lots can be identified by accelerated ageing (AA) test for Glycine max, which is an ISTA-validated vigor test (ISTA 2011, AOSA 2009). In addition, Electrical conductivity (EC) test of seed leachates provides a quick decision about seed vigor. High EC of seed is an indicator of seed membrane deterioration of lower quality seed. In this study, genotypic differences in soybean seed storability were observed. In particular, larger seeded soybean genotype Gazelle produced higher seed leachates and lower accelerated ageing germination \% values suggesting greater deterioration of seed membranes and enhanced ageing than in the smaller seeded TGx-1740-2F. In addition, since the initial vigor before storage was still higher for the smaller seeded TGx 1740-2F than larger seeded Gazelle, resistance to field weathering (Changrong et al. 2007) may have played a great role. Such genotypic differences in resistance to field weathering and storability of seed have been found by various researchers. Soybean lines with small seed size and/or black seed coats have been shown to exhibit greater resistance to field weathering than large seeded types with lighter colored seed coats (Horlings et al. 1991). Sung (1992) showed that soybean seed size had a direct effect on seed germination and vigor. Wien \& Kueneman (1981) on the other hand found consistent differences in storability among soybean lines, with some small-seeded lines maintaining more than 50\% germinability after 8 months of adverse ambient storage than large seeded ones; while Saranga et al. (1998) found that seed vigor was negatively correlated with embryo mass and that large seeds germinated and emerged later than small seeds. Similar results were obtained by Peksen et al. (2004) in pea (Pisum sativum L.); which revealed that cultivars with low 100 seed weight had higher germination percentage than larger seed ones. In soybean, Rastegar \& Kandi (2011) reported that smaller seeded cultivars had better germination uniformity and got food reserves to seedlings more and faster than for larger seeded ones. Hence the differences observed in the current study on soybean seed viability and vigor highlights variations in resistance to field weathering and in storability of soybean genotypes; since the smaller seeded genotype TGx 1740-2F resisted the negative consequences of ageing and stored better than larger seeded Gazelle after 8 months of ambient storage in Meru South Sub-county. These results demonstrate that seed deterioration and eventual seed storage life may be dependent on genetic factors.

\section{Effects of agro-ecological conditions on storability of soybean seed}

During storage, temperature, moisture, and time are critical factors affecting physical, physiological and biochemical changes that impact seed properties. These changes include loss of viability, grain color changes, alterations in moisture content, decomposition of lipids, degradation of protein, and damage to plasma and organelle membranes (Bailly et al. 1996, 1998, Kumar et al. 1999). Losses in seed quality occur during field weathering, harvesting and storage, and are exacerbated if seeds are exposed to high temperatures and/or humidity (Basra et al. 2000). After storage for 8 months, variations in seed storability due to storage agroecological conditions were evident in the current study. The reduced seed storability in the warmer LM4 was associated with increased electrolyte leakage and lower accelerated ageing germination $\%$. Temperature changes may have played a greater role than moisture in the stored seed because all moisture content values ranged from $7.4 \%$ to $9.4 \%$ which was within acceptable levels for seed storage hence were unlikely to adversely affect seed longevity. However, the upto $6^{\circ} \mathrm{C}$ higher temperature at warmer Lower Midlands IV agro-ecology may have caused accelerated seed deterioration than in seed stored at the cooler Upper Midlands II. These results agree with those reported elsewhere that unfavorable storage conditions (high air temperature and high humidity of air) accelerate seed deterioration, leading to losses in seed germination and vigor of stored seed (Burris 1980, Tewari \& Gupta 1981, Harrington 1973, Chirchir et al. 2016). Warmer storage temperatures cause higher levels of lipid peroxidation (Buchvarov \& Gantcheff 1984) and enzymatic activity leading to increase in the permeability of seed membranes (Ching \& Schoolcraft 1968), increased electrolyte leakage at germination, higher pathogen loads (Copeland \& McDonald 1995) and eventual death of the seed while in storage. From the 
current study, soybean seed storage agro-ecology significantly influenced vigor of soybean with the cooler higher Upper Midlands II agro-ecology of Kirege providing a better storage environment than the warmer Lower Midlands IV agro-ecology of Igambatuntu of Meru South Sub-county.

\section{CONCLUSION}

The genotype by environment interactions played a key role in storability of soybean genotypes. The smaller seeded soybean TGX 1740-2F was better storer seed than larger seeded Gazelle and seed should be stored for shorter periods of up to 123 days (4 months) for better viability and vigor. In addition, storing soybean seed in cooler higher elevations (UM2) of Kirege maintained seed of higher seed germination and vigor than storage in the lower warmer elevations (LM4) of Igambatuntu of Meru South Sub-county.

\section{ACKNOWLEDMENT}

We acknowledge the National Commission for Science, Technology and Innovation for partially funding this study and the Genetic Resources Research Institute for providing the seed testing laboratory facilities. We acknowledge the two farmers from Meru South sub-county - Mrs. Leah Gicheru and Mrs. Lucy Moffat who provided their stores for the soybean seed storage experiment. There was no conflict of interest related to this work.

\section{REFERENCES}

AOSA (2009) Baalbaki R, Elias S, Marcos-Filho J \& McDonald MB (eds) Seed vigor testing handbook. Contribution 32. AOSA, Ithaca, NY.

Bailly C, Benamar A, Corbineau F \& Come D (1996) Changes in malondialdehyde content and in superoxide dismutase, catalase and glutathione reductase activities in sunflower seeds as related to deterioration during accelerated aging. Physiologia Plantarum 97: 104-110.

Bailly C, Benamar A, Corbineau F \& Come D (1998) Free radical scavenging as affected by accelerated ageing and subsequent priming in sunflower seeds. Physiologia Plantarum 104: 646-652.

Balešević-Tubić M, Tatić V, Đorđević Z, Nikolić J \& Subić Đukić V (2011) Changes in soybean seeds as affected by accelerated and natural aging. Romanian Biotechnological Letters 6(6): 6740-6747.

Balešević-Tubić S, Tatić M, Đorđević V, Nikolić Z \& Đukić V (2010) Seed Viability of Oil Crops Depending on Storage Conditions. HELIA 33(52): 153-160.

Bellaloui N, Krishna N R, Bruns H A, Gillen AM, Mengistu A, Zobiole LH S, Fisher DK, Abbas HK, Zablotowicz RM \& Kremer RJ (2011) Soybean Seed Composition and Quality: Interactions of Environment, Genotype, and Management Practices. In: Maxwell JE (ed) Soybeans: cultivation, Uses and Nutrition. Nova Science Publishers, pp. 1-42. [ISBN: 978-1-61761-762-1]

Bentsink L, Alonso-Blanco C, Vreugdenhil D, Tesnier K, Groot SPC \& Koornneef M (2000) Genetic analysis of seed-soluble oligosaccharides in relation to seed storability of Arabidopsis. Plant Physiology 124: 15951604.

Buchvarov P \& Gantcheff T (1984) Influence of accelerated and natural aging on free-radical levels in soybean seeds. Physiologia Plantarum 60: 53-56.

Burris JS (1980) Maintenance of soybean seed quality in storage as influenced by moisture temperature and genotype. Iowa State Journal of Research 54: 337-389.

Changrong Y, Sripichitt, P. Juntakool S. Hongtrakul V \& Sripichitt A (2007) Modifying Controlled Deterioration for Evaluating Field Weathering Resistance of Soybean. Kasetsart Journal : Natural Science 41: 232-241.

Ching TM \& Schoolcraft I (1968) Physiological and chemical differences in aged seeds. Crop Science 8: 407.

Chirchir GJ , Mwangi M, Nyamongo DO \& Gweyi-Onyango JP (2016) Soybean farm-saved seed viability and vigor as Influenced by agro-ecological conditions of Meru South Sub-county, Kenya. Journal of Applied Biosciences 101: 9634-9642.

Coolbear P (1995) Mechanism of seed deterioration. In: Basra AS (ed) Seed Quality: Basic Mechanisms and Agricultural Implications. Food Product Press, New York, pp. 223-277.

Copeland LO \& McDonald MB (1995) Principles of seed science and technology, $3^{\text {rd }}$ edition. Chapman and Hall. New York, USA, pp. 409. 
Delouche JC (1965) A preliminary study of methods of separating crimson clover seeds on the basis of viability. Proceedings of the Association of Official Seed Analysts 55: 30-36.

El-Abady MI, El-Emam AAM, Seadh SE \& Yousof FI (2012) Soybean Seed Quality as Affected by Cultivars, Threshing Methods and Storage Periods. Research Journal of Seed Science 5: 115-125.

Harrington JF (1973) Biochemical basis of seed longevity. Seed Science and Technology 1: 453-461.

Horlings G, Gamble, EE \& Shanmugasundaram S (1991) The influence of seed size and seed coat characteristics on seed quality of soybean in the tropics: field weathering. Seed Science and Technology 9: 665-685.

ISTA (2007) Nijënstein H, Nydam J, Don R \& McGill C (eds) ISTA Handbook on Moisture Determination. International Seed Testing Association (ISTA), Bassersdorf.

ISTA (2011) Proceeding of International Rules for Seed Testing. International Seed Testing Association (ISTA). Seed Science and Technology, 27, Supplement.

Jaetzold R, Schmidt H, Hornetz B \& Shisanya C (2006) Farm Management Handbook of Kenya Vol. II Natural Conditions and farm Management Information, $2^{\text {nd }}$ Edition PART C; East Kenya. Sub-Part $1 C$. Eastern Province, pp. 167-260.

Kumar GNM, Houtz LR \& Knowles NR (1999) Age-induced protein modifications and increased proteolysis in potato seed-tubers. Plant Physiology 119: 89-100.

Kurdikeri MB, Basavaraj GT, Hiremath MV \& Aswathanarayan SC (1996) Storability of soyabean (Glycine $\max ($ L.) Merrill) seed under ambient condition. Karnataka Journal of Agricultural Sciences 9: 552-554.

McDonald MB (1999) Seed deterioration: physiology, repair and assessment. Seed Science and Technology 27: 177-237.

Peksen E, Peksen A, Bozoglu H \& Gulumser A (2004) Some seed traits and their relationships to seed germination and field emergence in pea (Pisum sativum L.). Journal of Agronomy 3: 243-246.

Rastegar Z \& Kandi MAS (2011) The effect of salinity and seed size on seed reserve utilization and seedling growth of soybean (Glycine max). International Journal of Agronomy \& Plant Production 2: 1-4.

Saranga Y, Levi A, Horcicka P \& Wolf DS (1998) Large sunflower seeds are characterized by low embryo vigor. Journal of American Society of Horticultural Science 123: 470-474.

Basra SMA, Rehman KU \& Sajjad I (2000) Cotton Seed Deterioration: Assessment of Some Physiological And Biochemical Aspects. International Journal of Agriculture \& Biology 2(3): 195-198

Shelar VR (2002) Role of mechanical damage in deterioration of soybean seed quality during storage, Ph.D. Thesis, MPKV, Rahuri (MS).

Singh CB, Dalal MA \& Singh SP (1978) Genetic analysis of field germination in soybean (Glycine max. (L) merill.). Theoretical and Applied Genetics 4: 165-169.

Sung FJM (1992) Field emergence of edible soybean seeds differing in seed size and emergence strength. Seed Science and Technology 20: 527-532.

Tatipata A (2009) Effect of seed moisture content, packaging and storage period on mitochondria inner membrane of soybean seed. Journal of Agricultural Technology 5(1): 51-64.

Tewari MN \& Gupta PC (1981) Effect of genotype, seed grade and environment on viability and vigor of sunflower seed in storage. Seed Research 9: 126-131.

Wien HC \& Kueneman EA (1981) Soybean seed deterioration in the tropics. II. Varietal differences and techniques for screening. Field Crops Research 4: 123-132. 